\title{
Intravitreal Implant in Applicator
}

National Cancer Institute

\section{Source}

National Cancer Institute. Intravitreal Implant in Applicator. NCI Thesaurus. Code C149624.

Medicinal product consisting of an intravitreal implant presented in an applicator. 